\title{
International Co-operation in Science and Technology: Concepts, Politics, and Dynamics in the Case of Argentine-Brazilian Nuclear Co-operation
}

\section{Bernabé Malacalza*}

\begin{abstract}
This article discusses the political dynamic of agenda-setting in the subfield of international nuclear co-operation, within an analytical framework that integrates the literature on international co-operation in science and technology, international nuclear co-operation, and foreign policy analysis. It presents the emblematic case of Argentine-Brazilian co-operation about the construction of two multipurpose reactors, whose process of decision-making has been disputed by officials, technological firms, managers, and nuclear scientists. It also underlines that economic and commercial motivations prevail in the process of international co-operation.
\end{abstract}

Key words: International Co-operation; Science and Technology; Foreign Policy Analysis; International Nuclear Co-operation.

\section{Introduction}

This article discusses international co-operation in science and technology (S\&T) in the field of nuclear applications, and seeks to improve our understanding of the political dynamic of the agenda-setting process in this area, and the articulation of actors and interests in domestic arenas. It does so by examining the role of presidents, ministries, nuclear commissions, technological firms and scientists in the particular case of Argentine-Brazilian co-operation about the construction of two multipurpose reactors: the Reator Multiproposito Brasileiro (RMB), and the Argentine reactor RA-10. The political dynamic of nuclear co-operation between these two countries is relatively new; as we will see, the institution established in 2008 to manage this process - the Binational Commission for

\footnotetext{
* National Scientific and Technical Research Council (CONICET), Universidad Nacional de Quilmes (UNQ), Buenos Aires, Argentina; b.malacalza@conicet.gov.ar..
} 
Nuclear Energy (COBEN, to use its Spanish acronym) - is also generating new demands for shared projects, as well as changes in the interpretive frameworks guiding bilateral relations in the nuclear field.

This is a case study. Drawing on the literature about S\&T international co-operation, international nuclear co-operation (INC), and foreign policy analysis, it assumes that INC is situated at the intersection between S\&T policy and foreign policy. In this particular case, the actors that concern us bring their own opinions and perceptions of INC into the analysis. Field research in Buenos Aires and Rio de Janeiro involved interviews with officials of the National Commission of Atomic Energy (CNEA), the Nuclear Regulatory Authority (ARN), the National Commission of Nuclear Energy of Brazil (CNEN), the Brazilian-Argentine Agency for Accounting and Control of Nuclear Materials (ABACC), and managers of the Argentine state-owned applied research company INVAP SE.

I briefly introduce the theoretical debate about the intersection between S\&T international co-operation and foreign policy, and discuss some of the theoretical implications of understanding INC as public policy. I then develop some explanatory hypotheses on four analytical levels (high politics, political-technical, market, and scientific-technological) in order to explain the current changes in incentives and capacities, the interpretive frameworks of actors, and the emergence of new institutional arrangements (such as COBEN) in the field of bilateral nuclear co-operation. Finally, I provide brief conclusions and recommendations, taking into account the growing role of S\&T international co-operation within the framework of foreign policy.

\section{International nuclear co-operation as public policy}

S\&T co-operation is as old as science. According to Wagner, Yesril and Hassell (2011), the visit of the Greek mathematician Archimedes (287-212 BC) to colleagues in Alexandria in Egypt may be the first registered case. Nevertheless, placing S\&T co-operation in the framework of international relations and international co-operation is much more recent, and remains at the development stage (Meirelles Ribeiro and Baiardi 2014).

Our point of departure is the intersection between the subfields of foreign policy analysis and S\&T policy. In terms of our own classification, the literature about S\&T international co-operation can be divided into two main groups: the first, more general in nature, and the second, more specific. The first group addresses the link between foreign policy and S\&T public policy. In her article 'Science and foreign policy: The elusive partnership', Caroline Wagner (2002) acknowledges that the current foreign policy agendas of states reflect the growing importance of scientific issues such as climate change, infectious diseases, and nuclear energy. As a consequence of this dynamic, both spheres often overlap: S\&T policy is becoming increasingly international and articulated with the foreign policy agenda, while foreign policy increasingly requires the sophistication and specialisation of S\&T policy in respect of certain complex issues. 
The reasons why S\&T public policy is becoming internationalised, and the incentives for scientists to co-operate, has been addressed in the general academic literature. In this regard, Wagner (2002) notes that scientists are motivated by five factors, namely to:

1. increase the visibility of and disseminate knowledge among colleagues;

2. share the costs of large-scale projects;

3. provide access to specialised and expensive material resources;

4. reach better results by sharing information; and

5. brainstorm ideas and exchange experiences for greater creativity.

By contrast, governments invest in S\&T international co-operation as a useful tool for:

6. achieving policy objectives (national defence, foreign relations, etc);

7. deploying specific public missions (energy, health); and

8. promoting knowledge (basic and applied science) that is closely linked to the economic development logic.

Another concern refers to the concept of international co-operation in S\&T, and its distinctive features. Major academic studies have focused on the study of the S\&T policy of the USA by stressing the presence of scientists and the exchange of sophisticated knowledge as the main characteristics of this form of co-operation. In this sense, Wagner, Yezril and Hassell (2001: 1) define international co-operation in S\&T as collaboration 'where scientists from different countries conduct join projects, or share common data towards a shared research goal'. On the other hand, Smith and Katz (cited in Wagner 2002) identify three models of science internationalisation from the perspective of foreign policy: (i) formal associations among scientific corporations; (ii) collaboration among research teams; and (iii) interpersonal collaboration (conferences, workshops, scholarships, databases, and so on. According to Wagner et al (2011), it is vital to emphasise that international cooperation in S\&T is marked by a bottom-up process that takes place more frequently at the level of individuals or scientists than at the level of organisations.

The second group of scholars explores the similarities and differences between the concepts of international co-operation in S\&T and international development co-operation (IDC). It remains unclear whether there are differences of degree between one modality and another, or whether we need to guarantee that we are not mixing apples with oranges. On the one hand, some scholars emphasise similarities between both forms of co-operation by acknowledging that international co-operation in S\&T is a subtype of IDC. As noted by Troyjo (2003), this co-operation is characterised by the need for particular minimum requirements, such as a certain equivalence of technical and scientific competencies among partners, and a common goal of knowledge transference and the application of science and innovation for development. Ayllón (2006) addresses this modality as part of the family of IDC, as are other modalities such as economic co-operation, trade preferences, financial aid, technical assistance, and humanitarian aid. Moreover, Sebastian (2007: 200) goes beyond convention by calling this modality 'scientific and technological co-operation for development'. Other scholars try to demonstrate that S\&T co-operation 
involves horizontal and symmetrical exchanges rather than asymmetrical and vertical ones in which the main relationship is between a developed and a developing country. Besides this, some academic studies tend to separate S\&T co-operation from IDC in order to highlight their differences. In this sense, Kern (2013) points out that both forms of cooperation have diverse ontological components: while IDC has 'the shared and absolute goal of promoting development', S\&T international co-operation pursues 'a political and strategic interest: to build up countries' own capacities by considering knowledge as a power resource' (Kern 2013: 85).

As stated by Meirelles Ribeiro and Baiardi (2014), 'today no modern state or society can ignore S\&T international co-operation'. In contrast with technical co-operation, this dimension of foreign policy is based on a particular type of transference, namely one that uses knowledge as a power resource. Meanwhile, unlike existing IDC, the developmental goal of this form of co-operation is related to the application of science and technology for innovation in productive sectors or for social inclusion purposes - particularly in the fields of health, food security and energy. Notably, within the framework of South-South co-operation, S\&T international co-operation is more the exception than the rule, because the minimum requirements of technological capacities and S\&T skills are seldom met in developing countries.

This article presents S\&T international co-operation as a dimension of foreign policy. Nowadays, it is widely acknowledged that science, technology, and international affairs affect each another. The intersection of foreign policy and S\&T policy arenas is marked by the challenge of dealing with two simultaneous processes: in the foreign policy arena, the increasing role of S\&T in international affairs of S\&T; and, in the S\&T policy arena, the increasing internationalisation of S\&T activities. Therefore, these fields need to be co-ordinated.

As a result, the intersection between foreign policy and S\&T policy can be characterised as the public policy of S\&T international co-operation. This space of convergence relates to the foreign policy-making process in two complementary ways. From the external perspective, it represents an important segment of foreign policy that affects the form and the effectiveness of bilateral relations, while constituting an archetype of a broad range of strategic problems involving the international projection of the state. Meanwhile, within the domestic environment, national endeavours in the field of S\&T become increasingly robust through co-operation with international actors and institutions as a means of accessing information, and disseminating knowledge and technologies.

Given the nature of these interrelated domains, S\&T international co-operation has to be addressed by international relations theory (IRT) as an international public policy inserted into the framework of global foreign policy. Maria Regina Soares de Lima (2013b) argues that the transformation of foreign policy analysis (FPA) is posing new challenges to IRT. According to Monica Hirst (2012: 11), the broadening of the scope of FPA beyond the boundaries of foreign affairs ministers allows scholars 'to perform an analytical monitoring' of the changing domestic process of foreign policy-making and its multiples issues and dynamics. As demonstrated by Carlos Milani and Leticia Pinheiro (2013), this raises 
the important issue of studying foreign policy as public policy, by taking into account the participation and influence of a wide range of political, economic and social actors such as the legislative power, the judicial power, labour unions, companies, NGOs, social movements, and so on. This does not mean that we should ignore the fact that government remains responsible for public policies - in a pyramidal understanding, the executive power vested in the president - and is either exercised directly, or delegated to officials charged with authorising and implementing foreign policy initiatives (Malacalza 2014).

The construction of public policy agendas has been debated in political science and public policy analysis. Since the study of Kingdon and Thurber (1984), agenda-setting has been defined as the process of 'selecting from among all possible problems or subjects those that are worthy of priority attention by decision-makers' (cited in Durant and Diehl 1989: 180). However, the explanation of decisions has to take into account the constituencies of policies: the varying and specific features of the environment, and the nature of the actors, fields of actions, and priorities involved in each issue area of public policy.

As an aspect of foreign policy, S\&T international co-operation is also subdivided into thematic spheres. Thus, INC is a subtype of this form of co-operation in which the agenda-setting process is marked by the multidimensionality and scale of big science. INC emerges as a particular and strategic aspect of the international co-operation agenda. In contrast with other forms of co-operation, the creation of a public agenda is a closed and sensitive process. Given the high level of specialisation and the dual character of this technology, there is a little room for manoeuvre in negotiations, and transactions - formal and informal - are controlled by a small group of actors: the president, ministers, the statutory authorities of the nuclear sector, and the managers of high-tech companies.

In line with a commonly accepted definition in INC academic literature, Matthew Fuhrmann (2009: 192) asserts that nuclear civil co-operation is 'the state-authorized transfer of nuclear facilities, technology, material, or know-how from one country to another for peaceful purposes'. This concept captures 'all transfers enabling the recipient country to develop, successfully operate, and expand a civil nuclear program. Operationally, there are five general categories of civilian nuclear co-operation: (1) reactors, (2) nuclear materials, (3) fuel-cycle facilities, (4) nuclear safety, and (5) intangible transfers (e.g. knowledge)'

One of the main characteristics of INC, according to Fuhrmann's definition, is multidimensionality, since it covers both knowledge (S\&T transfers) and trade (goods \& services tech exports) exchanges. Moreover, INC constituencies involve not only civil officials, scientists and individuals, but also the military and defence sectors, as in the case of the Brazilian Navy's nuclear propulsion programme. These specificities must be taken into consideration in analysing INC as a particular subtype of S\&T international co-operation. Nuclear trade, nuclear investments, and nuclear knowledge exchanges are parts of INC, but they have different logics. The following table shows the general concepts explained in this article, and the different dimensions of INC. First, it is relevant to distinguish S\&T international co-operation from IDC. Second, within a conceptual framework associated with the nuclear sector, it is also important to underline the distinctive features of INC, international nuclear trade, and international nuclear investments. 
Table 1: Concepts related to international nuclear co-operation

\begin{tabular}{ll}
\hline $\begin{array}{l}\text { International development } \\
\text { co-operation }\end{array}$ & $\begin{array}{l}\text { Co-operation between countries with different levels of income and a shared } \\
\text { goal of promoting economic, social and economic development in the South, } \\
\text { in order to balance the } \\
\text { relationship with the North (Ayllón 2006). }\end{array}$ \\
\hline $\begin{array}{l}\text { S\&T international co- } \\
\text { operation }\end{array}$ & $\begin{array}{l}\text { Co-operation between countries with equal levels of S\&T capacities and a } \\
\text { common strategic goal of knowledge transference and the application of } \\
\text { science and innovation for development. }\end{array}$ \\
\hline $\begin{array}{l}\text { International nuclear co- } \\
\text { operation }\end{array}$ & $\begin{array}{l}\text { 'State-authorized transfer of nuclear facilities, technology, material, or } \\
\text { know-how from one country to another for peaceful purposes'. (Fuhrmann } \\
2009)\end{array}$ \\
\hline $\begin{array}{l}\text { International nuclear trade } \\
\text { Exports of reactors, nuclear material, nuclear services, and other products. } \\
\text { investments }\end{array}$ & $\begin{array}{l}\text { Expansion of business portfolios of nuclear technology firms (state-owned, } \\
\text { semi-public or private). This process can be stimulated by the provision of } \\
\text { state loans. }\end{array}$ \\
\hline
\end{tabular}

Source: compiled by the author.

INC has a specific decision-making dimension not found in other areas of S\&T international co-operation. Apart from its multidimensionality, an essential feature of this process is its scale. This sort of collaboration corresponds to a big science project, like thermonuclear fusion, or human genome sequencing. According to Kinsella (1996: 65), big science involves the motivation and coordination of large numbers of people; the legitimation of, and advocacy for, substantial public funding; and the transformation of contestable knowledge claims into accepted facts through persuasive argumentation within extended scientific communities'. As Madison (2000: 38) notes:

[T] he size, cost, degree of qualitative change in knowledge, the necessity to conduct research utilizing broad institutional collaborations involving researchers skilled in many subfields of knowledge and the substantial social, economic, and political significance attributed to these efforts as symbols of national leadership and pride are clear indicators of the large scale change contemplated by a big science initiative.

Given these substantial properties, the decision-making process is fundamentally different because it takes place in a closed political context in which the agenda is shaped by a few groups only. Sábato and Ramesh (1980: 84) argue that nuclear energy needs a supportive state, a broad industrial base, and a team of highly-qualified experts, but all three serve to strengthen the elitist feature of the decision-making process in big science. Despite all of this, according to Madison (2000: 36): 
[T]he outcome benefits the political, economic, or professional interest of each party to the alliance. Decisions are usually made by accommodation among the major protagonists, who happen to be members of scientific establishments. Policy-makers in government provide these individuals with substantial freedom in exercising influence on the focus and direction of research and a voice in the allocation of resources to support their priorities. ${ }^{1}$

As result of these interactions, '... everyone wins. Scientists win because the policy rewards foster their reputations and eminent status. Agency officials benefit through stable or growing programs and budgets'. For this reason, 'all the members of the alliances are mutually dependent on each other because no single party can move a policy initiative to the agenda of government' (Madison 2000: 36).

Drawing on Madison's theoretical and analytical framework, the purpose of this article is to explain how INC has come about in respect of nuclear research reactors (multipurpose reactors), and in the specific case of Brazilian-Argentine co-operation. It addresses the issue of the domestic construction of INC initiatives in Latin American countries by exploring three dimensions: (i) the interests of specific actors (who), (ii) the locus of the decisions (where); and (iii) the sorts of transactions (how) entered into by officials, scientists and business people in the nuclear sector.

The method used to achieve this goal is case study research. Gerring (2006) notes that 'for methodological purposes, a case study is best defined as an in-depth study of a single unit (a relatively bounded phenomenon) where the scholar's aim is to elucidate features of a larger class of similar phenomena. The results presented in this study are based on a variety of research tools: primary and secondary sources, data collection, and interviews with officials, scientists, and business people in the Argentinian and Brazilian nuclear sectors (CNEA, CNEN, INVAP and ministries). The aim of analysing the development of Brazilian-Argentine co-operation about nuclear research reactors as a prototypical case is to verify to what extent these countries' institutions and actors are as different as they seem to be at first sight. Thus, the methodology and theoretical framework must allow an analysis that goes beyond this case study, and copes with the theoretical issue of linking foreign policy and INC as two dimensions of international public policy that may interact profoundly at different levels of the decision-making process.

In line with Scartascini et al (2008: 16) on the nature of the public policy-shaping process, this article also tries to answer other secondary questions, namely: (i) Who are the key actors involved in this process? (ii) What powers do they have, and what roles do they play? (iii) What are their preferences, incentives and capacities? (iv) What are the main settings in which they interact, and the main characteristics of those settings? (v) What is the nature of these exchanges? 


\section{The evolution of international nuclear co-operation between Argentina and Brazil}

The bilateral relationship between Argentina and Brazil about nuclear issues has been discussed in the international relations literature since the 1980s. Prominent here are Hirst and Bocco (1989), Solingen (1996), de Andrade (2006), Alcañiz (2010), de Jesus (2011), Mallea (2012), Merke (2012), Patti (2013), Dawood and Herz (2013), Lima (2013a), Hurtado (2014) and Gadano (2014), among others. We also have the meticulous report of Carsales and Ornstein (1998) on Argentinian nuclear co-operation during the 1990s. In most cases, INC is analysed as an indicator of the possibilities for the integration and/or co-ordination of policies between these countries.

Historically, the Brazilian and Argentinian militaries had the nuclear field almost entirely to themselves. In both cases, the militaries 'were the first actors to take into account that the presence of an integrated national industry and the development of the atomic area could represent a possible solution to the dependence on coal and oil, which were perceived as indicators of vulnerability in both countries' (Hurtado 2014: 38). Besides this, scientists (physicists, engineers, technicians, etc) and officials of national nuclear commissions - CNEA and CNEN - also played a prominent role in the acquisition of nuclear scientific knowledge. In the Argentinian case, CNEA was directed by the military for most of its history since 1950, but its domination of the nuclear sector was lost following the return to democracy in 1983. In contrast, according to Ribero Andrade (2013), the Brazilian navy maintained its autonomy even after the democratic transition in the 1980s, and this enabled it to elaborate and develop a 'parallel programme', mainly focused on nuclear propulsion submarines and ultra-centrifugal fuels via the Centro Tecnológico da Marinha (CTMSP) and Centro Experimental Aramar in Sao Paulo. ${ }^{2}$

Many bilateral nuclear co-operation initiatives during the 2000s have been classified into one of four spheres: 'political', 'political-technical', 'market', and 'scientific knowledge'. In our case, in the political sphere, the Argentine and Brazilian presidents played a key role as the ultimate decision-makers who authorised a foreign policy path, or assented to a bilateral agreement. Ministers assisted them with designing and monitoring the various initiatives. In the political and technical sphere, officials of the national nuclear commissions received the demands of the nuclear sector and represented its interests, acting as intermediaries between the political authorities on the one hand, and scientists and technologists on the other. In the market sphere, nuclear technology firms (state-owned, semi-public or private) supported large-scale research programmes following the internationalisation of their portfolio investments and the extension of their exports of goods and services. Finally, in the scientific knowledge sphere, exchanges among scientists and their associations created transnational networks of knowledge aimed at ensuring financing, sharing information, and exchanging good practices (Alcad 2010: 151).

The foundation stones of bilateral nuclear co-operation are the agreements signed in Buenos Aires in 1980 - in the period of the military dictatorships - and the agreements signed in Foz do Iguazú in 1985 by the democratic presidents Raúl Alfonsín and José Sarney. This initial political agenda comprised three goals: (i) to ensure the supply of Argen- 
tinian zirconium to Brazil, and Brazilian enriched uranium to Argentina; (ii) to establish S\&T co-operation in nuclear materials; and (iii) to support a 'shared nuclear diplomacy' at the multilateral level (Hirst and Bocco 1989: 65). ${ }^{3}$

Table 2: Spheres and actors in the agenda-setting process in international nuclear co-operation

\begin{tabular}{ll}
\hline Spheres & Actors \\
\hline Political & Presidential and ministerial diplomacy \\
\hline Political-technical & National nuclear commissions \\
\hline Market & Technological firms \\
\hline Scientific knowledge & Scientific research centres \\
\hline
\end{tabular}

Source: Compiled by the author.

These political complementarities and mutual understandings were milestones on the way to the agreements of 1991 establishing the Brazilian-Argentine Agency for Accounting and Control of Nuclear Materials (ABACC), a binational agency playing an active role in the verification of the pacific use of nuclear materials that could be used, either directly or indirectly, for the manufacture of weapons of mass destruction (Brigagão and Valle Fonrouge 1998). ${ }^{4}$

In the technical and market spheres, the role played by public technological companies, which have increased their participation in the global nuclear market during the past decade, is important. In Argentina, the state-owned technological company INVAP has a recognised trajectory in the design, construction and export of research reactors. The best examples are the Peruvian RP-O y RP-10 in 1977 and 1988, the Algerian NUR in 1985, the Egyptian Etrr-2 in 1992, and the Australian OPAL in 2002, which was completed in 2007 (Thomas, Versino and Lalouf 2008). The company also participated in the design of radioisotope plants in Cuba in the 1990s and, more recently, in India and the USA, where INVAP is building two reactors and a plant for the private firm Coquí Pharma in Florida (Arguello 2014).

In turn, there is no other organisation in Brazil like INVAP, despite the big industrial complex dedicated to selling nuclear materials and producing natural and enriched uranium. The Brazilian firms Eletronuclear, Indústrias Nucleares do Brasil (INB) and Nuclebrás Equipamentos Pesados SA (NUCLEP) export reactor materials to Argentina, and also receive the assistance of the Brazilian Navy (CTMSO) and the Instituto de Pesquisas de Sao Paulo (IPEN-SP) (Le Prioux and Dos Santos 2011).

In the scientific-technological sphere, both countries have created transnational networks of knowledge about the peaceful use of nuclear technology. In 1998, the International Atomic Energy Agency (IAEA) launched the Regional Co-operation Agreement for the Promotion of Science and Nuclear Technology in Latin America and the Caribbean (ARCAL), ${ }^{5}$ a milestone in technical co-operation among Latin American countries, in- 
volving exchanges of experts, scholarships, scientific visits, training courses, and technology transfer (Casas Zamora and Kashyap 2013).

Currently, bilateral exchanges take place in at least three fields: (i) the multilateral field, in which the IAEA and the Nuclear Suppliers Group (NSG) ${ }^{6}$ play a prominent role; (ii) the regional field, where ARCAL is the main institutional mechanism for nuclear cooperation; and (iii) the bilateral field, involving bilateral meetings of presidents, ministers, and officials of CNEA, CNEN, ABACC and COBEN.

In all these areas, we point especially to the increased relevance of the COBEN as the most recent institutional framework for the exchange of information and sharing of joint projects. COBEN is the fifth of five binational forms of S\&T co-operation that have emerged from the maturing relationship between Argentina and Brazil since the early 1980s, and has a frustrated short-life antecedent: the Argentine-Brazilian Agency of Nuclear Energy Applications (ABAEN), which was established on 4 August 2001. ${ }^{7}$

The Presidential Joint Declaration - signed on 22 February 2008 - established three priorities for bilateral co-operation within COBEN: (i) the enrichment of uranium, (ii) the production of radio-pharmaceuticals; and (iii) the development of nuclear applications for health and agriculture. Against this backdrop, a Binational Seminar for Nuclear Cooperation took place in May 2008, with the participation of 75 experts from each country. The main result of these meetings was the approval of 35 nuclear co-operation projects in five areas: nuclear applications, fuel cycle, reactors and waste management, nuclear regulation, and the enrichment of uranium (CNEA 2009). ${ }^{8}$

Despite all its evident internal difficulties, such as its intermittence and informality as an institutional mechanism, COBEN has accomplished its original goal, and has also played a useful role in promoting dialogue and policy co-ordination between officials, scientists and technologists from both countries. This is perhaps best illustrated by the 2009 COBEN meeting, when officials and scientists from the respective nuclear commissions proposed the idea of the joint and simultaneous construction of the reactor RA-10 in Argentina, and the RMB (Reator Multipropósito Brasileiro) in Brazil, which will be analysed in the following section.

\section{The joint project for the construction of two research reactors}

The Joint RMB/RA-10 project was conceived between 2008 and 2009 to help address the global, regional, and local threats and challenges posed by the crisis in the radio-pharmaceutical market.

At the global level, the end of the usable life of the Canadian reactor NRU in July 2009 exacerbated the general shortage of radio-pharmaceutical Molibdeno-99. ${ }^{9}$ This directly affected the Brazilian nuclear medicine sector, which is strongly dependent on imports. Given this emergency situation, CNEA in Argentina - one of six world producers of Mo$99^{10}$ - offered to export radio-pharmaceutical Mo-99 to CNEN in Brazil, in order to cover its deficit of 2 million doses (one third of the national consumption). 
Research reactors that could be harnessed through bilateral co-operation yielded greater possibilities for regional co-operation than power reactors and nuclear plants. According to a manager of INVAP who was interviewed for this study:

[A] research reactor consumes 100 times less power and is 10 times lower in total cost than a nuclear plant. Nuclear plants are made following repetitive patterns, while research reactors are always made by custom demands, so in relative terms are more expensive. Apart from this, the world market of research reactors is the equivalent of one or two nuclear plants. In contrast, the world market of nuclear plants is 100 units each decade. The cost of a nuclear plant is 100 billion dollars, while the cost of a research reactor is 1 billion dollars. ${ }^{11}$

Apart from this, there is a great potential in the expansion of power reactors in Latin America. Brazil holds 5\% of world uranium reserves, Argentina has tried to double its nuclear energy production, and Mexico plans to build eight more power reactors by 2025 . However, according to Dawood and Herz (2013), there are some economic problems in the mining industry that make it difficult to reduce the regional dependence on hydrocarbons and hydroelectricity.

As result, a gap remains between research reactors and power reactors in Latin America. There are 16 research reactors (five in Argentina, four in Brazil, three in Mexico, two in Peru, one in Jamaica and one in Chile), compared to six power reactors in the three largest countries (three in Argentina, two in Brazil, and one in Mexico). ${ }^{12}$ These six reactors generate a very small proportion of the world's nuclear energy supply $(1,4 \%$ of the power generated by 430 power reactors worldwide), while the 16 research reactors represent a higher percentage $(6,5 \%$ of the power generated by 247 research reactors worldwide) (IAEA 2014).

This diagnosis also has to be compared with projections of future potential. Only eight of the 16 research reactors are intended for radioisotope production. Also, about half of their regional production capacity (31.6MW) is located in Argentina (33\%) and Brazil (16\%). By 2018, the two multipurpose reactors ${ }^{13}$ in these countries (the subjects of this case study) will significantly increase generating capacities: in Argentina, from 10.5 MW to $40.5 \mathrm{MW}$ (an increase of 44,3\%), and in Brazil from 5.1 MW to $35.1 \mathrm{MW}$ (an increase of $38,3 \%$ ) (IAEA 2014).

Table 3. Research reactors used for radioisotope production in Latin America

\begin{tabular}{llrl}
\hline Country & Name & (Kw) & Situation \\
\hline Argentina & RA-3 (Ezeiza) & $10 \mathrm{MW}$ & Operating since 1967 \\
\hline Argentina & RA-6 (Bariloche) & $0.5 \mathrm{MW}$ & Operating since 1982 \\
\hline Brazil & IEA-R1 (San Pablo) & $5 \mathrm{MW}$ & Operating since 1957 \\
\hline Brazil & IPR-R1 (Minas Gerais) & $0.1 \mathrm{MW}$ & Operating since 1960 \\
\hline Brazil & ARGONAUTA (RJ) & $0.2000 \mathrm{~kW}$ & Operating since 1965 \\
\hline
\end{tabular}




\begin{tabular}{llrl}
\hline Country & Name & (KW) & Situation \\
\hline Chile & RECH-1 (Santiago) & 5 MW & Operating since 1974 \\
\hline Mexico & TRIGA MARK III & 1 MW & Operating since 1968 \\
\hline Peru & RP-10 (Lima) & 10 MW & Operating since 1988 \\
\hline Argentina & RA-10 (Bariloche) & 30 MW & Under Construction (until 2018) \\
\hline Brazil & RMB (IPEN) & 30 MW & Under Construction (until 2018) \\
\hline
\end{tabular}

Source: Compiled by the author, based on IAEA (2014)

Besides global and regional changes, complementarities between Brazil and Argentina in the nuclear sector have been evident since the reactivation of their national nuclear energy projects in the past decade. The re-launching of nuclear plans has been a key element of public and private engagement with the development of the nuclear industry. This has led to a significant increase in budgets, which has also been an incentive for the expansion of national nuclear technology firms.

In Argentina, the export of the OPAL research reactor (Open Pool Australian Lightwater) to the Australian Nuclear Science and Technology Organization (ANSTO) in 2000, as well as its entry into service in 2006, was a significant turning point. From that point onwards, INVAP gained great prestige in the developed world, as well as an economic incentive to do business and expand its network of business relationships. As an INVAP manager has noted:

[T] here are many countries that are interested in dominating the field of nuclear technology and, in these cases, access to a research reactor can be a small vehicle to promote different activities such as the training of human resources, the improvement of nuclear quality systems, the establishment of regulatory systems, and the development of nuclear plants. A research reactor is also a gateway for nonnuclear countries to learn about nuclear energy. ${ }^{14}$

There is also a link between INVAP's development and the increase in public contributions over the past decade. Following greater demand by the Argentine government, the company started a plan to diversify. Beyond the nuclear area, INVAP experts have launched a broad and diverse range of projects in new areas such as oil engineering, civil and military radar, earth observation and communication satellites, open television, wind energy, nuclear medicine, and unmanned aerial drones.

In Brazil, the production of radioisotopes is not sufficient to cover domestic demand. Of the four research reactors in operation, only one - the IEA-R1 - is capable of producing radioisotopes. Moreover, its potential is limited to $4.5 \mathrm{MW}$, and it is 58 years old..$^{15}$ Given this lack of capacity, Brazilian nuclear medicine services are permanently on the verge of collapse.

The need to build a new reactor began to emerge in 2008 as an initiative of the Directorate of Special Projects/IPEN, headed by José Augusto Perrotta. Following the 
guidelines of the National Plan of Action of Science, Technology and Innovation (PACTI 2007-2010), a group of experts from CNEN and the Technological Centre of the Navy in Sao Paulo (CTM-SP) started to design a preliminary project for the RMB. One year later, IPEN began to explore the possibility for co-operation in this area, giving priority to linkages with France and Argentina. However, bilateral meetings held annually between Brazil and Argentina within the framework of COBEN and ABACC paved the way for new talks with INVAP managers from Argentina. Not surprisingly, INVAP's proposal would be to test and build a prototype similar to the OPAL reactor, the one sold to Australia, and this was a determining factor in the final choice of the Brazilian authorities.

The project was placed on the political agenda with a meeting between the Argentine minister of federal planning and the Brazilian minister of science and technology. In August 2010, the signing of the 'Presidential Joint Statement of San Juan' recognised the project as 'emblematic, and a high priority for the bilateral strategic relationship'. Within this presidential framework, the 2011 Ministerial Agreement officially initiated the joint building of RMB and RA- 10 .

While nuclear issues between Argentina and Brazil are dealt with at both the presidential and ministerial levels, all matters have their own dynamic and specific networks within a bilateral agreement or framework. Interviewees acknowledged that government (presidents and ministers) were responsible for all public policies, including nuclear policy, but also noted that nuclear agencies or specific actors, such as scientists who seek to build co-operation agendas, could obtain the authorisation of a primary actor - the president - that would provide any foreign policy agenda with the necessary authority (Milani and Pinheiro 2013). However, the plurality of actors and agendas has resulted in an increasingly complex decision-making process in which nuclear technology companies and research institutes play a significant role. ${ }^{16}$

In the case of the RMB project, two companies were the main precursors of the initiative: the Brazilian firm Intertechne, which in 2012 assumed responsibility for the conceptual and basic design of systems and infrastructure; and the Argentine company INVAP, which since May 2013 has been in charge of basic engineering. ${ }^{17}$ INVAP's proposal was to reduce costs by replicating the RA-10's format and prototype. Therefore, bilateral cooperation emerged as a consequence of the sale of technical services from INVAP to Rede de Tecnologia e Inovação of Rio de Janeiro (REDETEC). As already stated, nuclear trade and technical co-operation both helped to strengthen bilateral ties.

The coalition supporting the project was formed by IPEN-SP, the main precursor in Brazil, in co-operation with INVAP in Argentina, the knowledge supplier. These initiators shaped the preliminary project that was approved later during the COBEN meetings. As result, the joint presidential statement and ministerial agreements played the role of authorisers, supporting new budget arrangements, and facilitating symbolic and material resources for the project. This network of actors, agendas and arenas is reflected in the following table. ${ }^{18}$ 
Table 4: RMB/RA-10 joint project - spheres, actors and arenas

\begin{tabular}{|c|c|c|c|}
\hline \multirow[t]{2}{*}{ Spheres } & \multicolumn{2}{|c|}{ Actors } & \multirow[t]{2}{*}{ Arenas } \\
\hline & Argentina & Brazil & \\
\hline \multirow[t]{5}{*}{ High politics } & Presidents & & \multirow{5}{*}{$\begin{array}{l}\text { Presidential summits } \\
\text { and ministerial meetings }\end{array}$} \\
\hline & \multicolumn{2}{|l|}{ Ministers } & \\
\hline & Minister of Federal Planning & $\begin{array}{l}\text { Minister of Science and } \\
\text { Technology }\end{array}$ & \\
\hline & \multicolumn{2}{|l|}{ Other ministries } & \\
\hline & $\begin{array}{l}\text { Foreign Affairs (embassies) } \\
\text { Science, Technology and } \\
\text { Innovation }\end{array}$ & $\begin{array}{l}\text { Mines and Energy } \\
\text { Defence } \\
\text { Foreign Affairs (embassies) }\end{array}$ & \\
\hline \multirow{2}{*}{$\begin{array}{l}\text { Political } \\
\text { technical }\end{array}$} & \multicolumn{2}{|c|}{ Authorities in the nuclear sector } & \multirow{2}{*}{$\begin{array}{l}\text { Meetings between CNEN } 8 \\
\text { CNEA } \\
\text { COBEN meetings } \\
\text { ABACC meetings }\end{array}$} \\
\hline & Authorities of CNEA & Authorities of CNEN & \\
\hline \multirow[t]{4}{*}{ Market } & \multicolumn{2}{|l|}{ Technological firms } & \multirow{3}{*}{$\begin{array}{l}\text { CAE/CNEA } \\
\text { (Ezeiza Argentina) } \\
\text { Aramar, Iperó SP (Sao } \\
\text { Paulo). }\end{array}$} \\
\hline & INVAP S.E. & $\begin{array}{l}\text { Intertechne (Curitiba) } \\
\text { REDETEC (RJ) }\end{array}$ & \\
\hline & \multicolumn{2}{|l|}{ Other firms involved } & \\
\hline & $\begin{array}{l}\text { DIOXITEC } \\
\text { FUESMEN } \\
\text { Nuclear Medicine Centres }\end{array}$ & $\begin{array}{l}\text { NUCLEP, Eletronuclear, } \\
\text { Indústrias Nucleares do } \\
\text { Brasil (INB), } \\
\text { Empresa Brasileira de } \\
\text { Radiofármacos (EBR) } \\
\text { Nuclear Medicine Centres }\end{array}$ & $\begin{array}{l}\text { INVAP (Bariloche) } \\
\text { CNEN } \\
\text { (Rio de Janeiro) }\end{array}$ \\
\hline \multirow{2}{*}{$\begin{array}{l}\text { Scientific } \\
\text { knowledge }\end{array}$} & \multicolumn{2}{|l|}{ Scientists and technologists } & Sao Paulo \\
\hline & $\begin{array}{l}\text { Project RA10 } \\
\text { CNEA } \\
\text { INVAP SE }\end{array}$ & $\begin{array}{l}\text { Project RMB } \\
\text { CNEN } \\
\text { IPEN-SP } \\
\text { CTMSP (Aramar) }\end{array}$ & $\begin{array}{l}\text { Buenos Aires } \\
\text { Bariloche }\end{array}$ \\
\hline
\end{tabular}

Source: Compiled by the author, based on interviews and field work.

S\&T co-operation also has the potential to improve international relations. According to Flink and Schreiterer (2010: 676),

science and collaborative research work are no panacea for easing conflicts or improving stale relations between nations. Nevertheless, they may become important incubators for international co-operation ... and for the cultivation of civil relations that are based on mutual respect, shared values, and common standards in the global company of science.

In this instance, various factors have contributed to the politicisation of RMB/RA10 projects. Multiple incentives in at least four fields have converged on the same goal of 
promoting bilateral co-operation, reaching a plateau in the nuclear arena. The four fields are as follows:

a. High politics: S\&T co-operation is regarded as a priority because of its significant contribution to the strengthening of international relations with middle or subregional powers such as Argentina, or BRICS countries, such as Brazil. However, the degree to which S\&T co-operation is guided by offensive (promoting influence) or defensive (maintaining national capacities) objectives or by a blend of all these varies considerably.

b. Political-technical field: S\&T co-operation is an incentive for national nuclear commissions (CNEA and CNEN), because it strengthens the weight and autonomy of the nuclear sector, and therefore its capacity to assist in the domestic struggle for resources.

c. Market field: S\&T companies are interested in deeper S\&T co-operation in order to expand product designs, grow sales, develop new markets, and increase incomes. The regional market for nuclear materials, radioisotopes, and technical services requires public financing as a stimulus for this strategic area.

d. Scientific knowledge field: Researchers and scientists have major incentives to co-operate. Nuclear research centres require financing to ensure their continued existence, and exchanges of information play a key role in the development of sophisticated projects.

These multiples incentives illuminate the location of international collaboration in S\&T at the intersection of S\&T policies and foreign affairs. It encompasses presidents, ministers, diplomats, business entrepreneurs and scientists, who determine what is feasible and what is not in nuclear co-operation (Flink and Schreiterer 2010).

Having established how S\&T international co-operation unfolded in the case of RMB/ RA-10, we now need to ask: why did these countries decide to deepen S\&T co-operation within the nuclear arena, and beyond their competitive interests? They had various reasons for doing so, but the main reason was the convergence between the interests of governments, technological firms and scientists towards a common economic developmental goal. As the general manager of INVAP, Héctor Otegui, has noted:

[I]f we had made one reactor, we would have had to pass on the full cost of the engineering to one reactor. But the making, simultaneously, of two reactors reduced the price per unit. That was our synergetic effect. In fact, the Argentinian reactor is now more developed because our basic engineering is almost finished, and after this stage our workers will be able to change from the Argentine reactor to the Brazilian reactor (Krakowiak 2013).

This mutual economic benefit is derived from the sharing of basic engineering in order to reduce common transaction costs, which underlines that economic and trade motivations have played a major role in driving this project. As a result, S\&T co-operation 
could be defined as a byproduct of this entrepreneurial logic, which has played a major historical role in bilateral relations.

The wide range of non-government actors within the INC system (firms, universities, research centres, and nuclear medicine centres) have developed their own internationalisation strategies. However, while technology companies such as INVAP have retained a degree of operational autonomy, their internationalisation has follows the patterns established by governments as well as the incentives and opportunities provided by public financing, the first source of support of S\&T co-operation in each country. Therefore, trade relationships within the nuclear sphere is the prelude to S\&T international co-operation. However, as an interviewee pointed out, there is no point in trying to identify when and where each sphere starts or ends, as it leads to the rhetorical question: which came first, the chicken or the egg? ${ }^{19}$

\section{Conclusion}

Returning to Madison's model, it is important to acknowledge that presidential diplomacy has played a key role in setting the agenda for Argentine-Brazilian nuclear co-operation, because presidents still take the 'final decisions' to authorise or reject any foreign policy action, including INC initiatives. However, governments have a limited menu of options, designed by technological entrepreneurs who base the direction and contents of their research on their economic and trade motivations. The internationalisation of technological companies also helps to expand S\&T co-operation, but this process still lacks the precision provided by universities and research centres, which are the most natural implementers of projects in the nuclear field.

This analysis of Argentine-Brazilian nuclear co-operation has highlighted some significant changes. The most important one is the emergence of COBEN, which has become the main forum for bilateral discussions in the nuclear sector. It has also become the main platform for meetings between policy-makers and stakeholders, where government officials, scientists, and company representatives, and representatives of other organisations active in the sector are able to collaborate on designing common S\&T policy agendas. Despite its intermittence as an institutional mechanism, collaboration between Argentina and Brazil within COBEN represents a major step towards building common institutions, and a leap in quality compared to the earlier ABAEN.

In turn, S\&T co-operation in this instance has followed the logic of complementarity among countries with different capacities and profiles. Argentina has the technical knowledge needed to design and build research reactors, and the ability to place this in the market. More specifically, INVAP has a wealth of experience and expertise in the production and commercialisation of 'turnkey' research reactors and radioisotopes plants. While Brazil does not have a technical firm like INVAP, and has not yet exported a research reactor, the Brazilian government is playing an important role in nuclear development via public sector planning and financing. 
This article has demonstrated that S\&T co-operation between Argentina and Brazil developed in a favourable environment, guided by common respect for the principle of mutual benefit. Brazil sought to gain access to know-how in the area of nuclear applications, while Argentina sought to gain access to the Brazilian market as well as public financing. The collaboration has been a win-win for both countries, because it has enabled technological firms to internationalise their portfolios, reduce transactional costs, improve the mobility of scientists, and encourage the civil construction, technological, and other relevant industries.

In the process, Argentine-Brazilian nuclear co-operation has surpassed previous levels of rapprochement from the original monitoring, which continues under ABACC, to the design and implementation of joint projects discussed in COBEN. This represents a new phase in bilateral relations.

Nevertheless, heightened INC also brings with it complex issues and problems that require higher levels of understanding and co-operation. More specifically, S\&T policy and foreign policy require even higher levels of co-ordination. The case study presented in this article demonstrates the growing importance of S\&T in international affairs, as well as the role played by foreign policy in scientific issues. The field of big science is particularly significant because it requires huge resources, high-quality scientists, and clearly defined political objectives.

Our case study also illustrates the interaction between three types of agendas: political; economic and commercial; and scientific and technological. In this instance, INC is mainly explained by political factors such as the active roles of presidential and ministerial diplomacy, and the growing relevance of S\&T in the public agendas of both countries. On the other hand, the economic explanation stresses the internationalisation of technology companies such as INVAP, which function as a driving force for trade and investments, paving the way for new projects and initiatives. As a result, in this instance, the scientific and technological agenda was subordinated to the economic one. There was no autonomous collaboration between scientists, apart from their direct involvement in the project. This issue should be treated as a priority in order to increase the levels of S\&T bilateral exchanges beyond nuclear business. A binational centre for research in nuclear applications may provide universities and research centres in both countries with a good platform for engagement.

The main motivation for developments in the nuclear field since the early 1980s has been the exchange of information. This drove the establishment of ABACC in 1991, and the shared work in COBEN since 2008. The current challenge is to strengthen information exchange by adopting a common and institutionalised approach to the acquisition of scientific knowledge. This would require modifying the conservative management of scientific knowledge in both countries, and improving co-ordination efforts aimed at making greater use of nuclear energy. In turn, this would require overcoming prejudices inherited from the past, as well as negative stereotypes of 'the other'. Above all, this is a political imperative, because the socialisation of scientific knowledge is also essential for 
strengthening other public sectors related to the nuclear field, such as health, industry, and agriculture.

\section{Notes}

1 This point was also highlighted by different interviewees. Interviews with Julian Gadano, deputy president of the Argentinian Nuclear Regulatory Authority (ARN), 13 May 2014; and Sonia Fernandez Moreno, Planning and Evaluation Officer, ABACC, 13 August, 2014.

2 Interview with Ana Ribeiro de Andrade, 11 August 2014.

3 As highlighted by Hirst and Bocco (1989), the launch of the Brazilian Nuclear Parallel Programme in 1979 coincided with the signing of the Agreements of Buenos Aires in 1980. Some scholars explain these understandings in terms of technological complementarities. Argentina had sufficient reserves of uranium (heavy water), and needed access to enriched uranium technologies in order to complete the control of its fuel cycle. In the meantime, the Brazilian Nuclear Programme, which was totally dependent on American co-operation because of its technological option for enriched uranium (light water), had suffered the consequences of the atomic explosion in India in 1974, and the hardening of US non-proliferation policy during the Carter administration.

4 ABACC is the only binational safeguards organisation in the world, and the first binational organisation created by Argentina and Brazil. As a regional agency dealing with safeguards, its main goal is guaranteeing to Argentina, Brazil and the international community that all nuclear materials are used exclusively for peaceful purposes. For more, see www.abacc.org.br.

5 The ARCAL programme links domestic institutions of nuclear technology with the IAEA. It was established in 1984, and became a formal intergovernmental agreement in 1998. Twenty one Latin American countries are engaged in this programme, which has the following common goals: (i) the transnational training of nuclear professionals; (ii) the establishment and maintenance of new and existing laboratories; (iii) the standardisation of nuclear techniques in the region; (iv) the creation of regional systems, such as the Regional Network of Techniques for Nuclear Agriculture created in 1995; and, (v) the dissemination of nuclear knowledge through reports, guides, bibliography, etc (PER-ARCAL 2014).

6 The NSG was created in 1974, after India had tested its first nuclear weapon. Its main purpose is to evaluate and authorise the transfer of nuclear material between countries, in order to prevent the proliferation of nuclear weapons. It consists of 49 countries, all exporters of nuclear technology, and is currently chaired by Argentina.

7 The other binational entities are the Argentine-Brazilian Centre of Biotechnology (CABBIO), created in 1986; the Argentinian-Brazilian Centre of Nanoscience and Nanotechnology (CBANN), created in 2005; and the Argentinian-Brazilian Centre of Metrology (CABM), created in 2007.

8 One of the main projects is the creation of the Binational Company for the Enrichment of Uranium (EBEN). This has been postponed, given the multiplicity and complexity of proposals that have to be studied. More recently, both countries have requested a technical study to assess the feasibility of the project.

9 The Canadian reactor NRU accounts for one third of all production of radioisotopes. In 2009, a maintenance stoppage at the NRU caused a market shortage that affected nuclear medicine services in Brazil (CNEA 2009).

10 The other five producers of Mo-99 are the NRU in Chalk River, Canada (57 years); the BR-2 in Mol, Belgium (53 years); the HFR in Petten, The Netherlands (53 years); the Osiris in Saclay, France (58 years); and the Safari-1 in Pelindaba, South Africa (59 years). (IAEA 2010)

11 Interview with Juan Pablo Ordoñez, INVAP deputy manager of nuclear projects, 25 June 2014.

12 According to Arguello (2009), at least five more Latin American countries - Chile, Venezuela, Uruguay, Peru and Cuba - are interested in accessing nuclear technology.

13 According to the technical definition, a Multipurpose Reactor (MR) focuses on neutrons released during nuclear fission. The neutrons are used to adjust patterns in models of 10MW. There are at least four types of MR: (i) neutron-scattering reactors: they illuminate the matter and this action allows them to make a 
diagnosis; (ii) producers of radioisotopes reactors: they are useful for diagnosis in medicine; (iii) nuclear plants reactors: they are useful for irradiation of materials; and (iv) producers of silicon doped reactors: they provide material for building computing microchips. As was pointed out by an interviewee, of these four uses the OPAL reactor sold to Australia does not have the third use, but the RA-10 and the RMB will provide all the uses. Interview with Juan Pablo Ordoñez, INVAP.

14 Interview with Juan Pablo Ordoñez. INVAP deputy manager of nuclear projects, 25 June, 2014.

15 Interview with Chao Tsu Chia, General Coordination of International Affairs, National Commission of Nuclear Energy (CNEN), Brazil, 11 August 2014.

16 Interview with Viviane Simões, General Coordination of International Affairs, National Commission of Nuclear Energy (CNEN), Brazil, 13 August, 2014

17 The contract was signed between Rede de Tecnologia e Inovação of Rio de Janeiro (REDETEC) and INVAP in May 2013 for a one-year period with a total value of 8 million US dollars.

18 The total financing of the RMB project was about 500 millon dollars, which includes access to a total surface area of $2.054 .000 \mathrm{~m} 2$ (4700 m2 in infrastructure) in Iperó.

19 Interview with Juan Pablo Ordoñez. INVAP Deputy Manager of Nuclear Projects, 25 June, 2014.

\section{References}

Alcañiz, Isabela. 2010. 'Bureaucratic networks and government spending: a network analysis of nuclear co-operation in Latin America' Latin American Research Review 5 (1): 148-172.

Arguello, Irma. 2014. 'Argentina entre los grandes proveedores globales de reactores nucleares'. Tiempo Argentino. 24 September. Available at: http://tiempo.infonews.com/nota/141077/argentinaentre-los-grandes-proveedores-globales-de-reactores-nucleares [accessed on 3 January 2015].

Ayllón, Bruno. 2006. 'O sistema internacional de cooperação ao desenvolvimento e seu estudo nas Relações Internacionais: a evolução histórica e as dimensões teóricas'. Revista Economia e Relações Internacionais, FAAP, São Paulo, 5(8).

Brigagão, Clovis and Marcelo Valle Fonrouge. 1998. 'Argentina and Brazil: A Regional Model of Confidence Building for Nuclear Security'. International Journal of Peace Studies: 99-108.

Carsales, Julio and Roberto Ornestein. 1998. La cooperación internacional de la Argentina en el campo nuclear. Buenos Aires: Consejo Argentino de Relaciones Internacionales.

Casas Zamora, Juan Antonio and Ridhi Kashyap. 2013. 'The IAEA technical co-operation programme and nuclear medicine in the developing world: objectives, trends, and contributions'. Seminars in nuclear medicine 43 (3). London: WB Saunders.

CNEA. 2010. 'CNEA vende radioisótopos a Brasil'. Available at: http://www.cnea.gov.ar/noticiasdetalle?nid=2093 [accessed on 5 January 2015].

2009 Memoria y balance 2009. Buenos Aires: CNEA. Available at: www.cnea.gov.ar/sites/ default/files/cap1_7.pdf [Accessed on 5 January 2015].

Dawood, Layla and Monica Herz. 2013. 'Nuclear governance in Latin America. Contexto Internacional 35(2): 497-535.

De Andrade, Ana María Ribeiro. 2006. A opção nuclear: 50 anos rumo à autonomia. Rio de Janeiro: CNEN.

De Jesus, Diego Santos Vieira. 2011. 'Desde Angra hacia Teherán: la política nuclear brasileña bajo la administración Lula'. América Latina Hoy 58: 103-120. 
Durant, Robert and Paul Diehl. 1989. 'Agendas, alternatives, and public policy: Lessons from the US foreign policy arena'. Journal of Public Policy 9(02): 179-205.

Flink, Tim and Ulrich Schreiterer. 2010. 'Science diplomacy at the intersection of S\&T policies and foreign affairs: toward a typology of "national approaches"'. Science and Public Policy vol. 37(9): 665-677.

Fuhrmann, Matthew. 2009. 'Taking a Walk on the Supply Side The Determinants of Civilian Nuclear Co-operation'. Journal of Conflict Resolution 53(2): 181-208.

Gadano, Julián. 2014. 'El desarrollo nuclear pacífico argentino: factores que lo hicieron posible y algunas hipótesis sobre su futuro'. Paper delivered at FLACSO-ISA Joint International Conference. Buenos Aires, 21 October 2014. Available at: http://web.isanet.org/Web/Conferences/FLACSOISA\%20BuenosAires\%202014/Archive/7fec6f76-07a2-4f90-ad1e-91f769c67d11.pdf [Accessed on 5 January 2015].

Gerring, John. 2006. Case study research: principles and practices. Cambridge: Cambridge University Press. Hirst, Monica. 2012. 'Prólogo'. In Carlos Milani and Leticia Pinheiro. Política externa brasileira: As práticas da política e a política das práticas. Rio de Janeiro: FGV.

Hirst, Monica and Hector Bocco. 1989. 'Cooperação nuclear e integração Brasil-Argentina'. Contexto Internacional 5(9).

Hurtado, Diego. 2014. El sueño de la Argentina Atómica. Buenos Aires: Edhasa.

IAEA. 2010. Nuclear Technology Review 2010. Ginebra: IAEA. Available at: http://www.iaea.org/About/ Policy/GC/GC54/GC54InfDocuments/English/gc54inf-3_en.pdf [Accessed on 5 January 2015].

2014. Research reactors. Ginebra: IAEA. Available at: http://nucleus.iaea.org/RRDB/RR/ReactorSearch.aspx [Accessed on 5 January 2015].

Kern, Alejandra. 2013. 'Oportunidades y desafíos de la cooperación científica y tecnológica para los Países de Renta Media' In Miriam Colacrai (ed), La Cooperación Internacional desde la visión de los PRM: discusiones conceptuales, diseños de políticas y prácticas sudamericanas. Rosario: UNR.

Kingdon, John and James Thurber. 1984. Agendas, alternatives, and public policies. Vol. 45. Boston: Little, Brown.

Kinsella, William J. 1996. 'A "fusion" of interests: Big science, government, and rhetorical practice in nuclear fusion research'. Rhetoric Society Quarterly vol. 26(4): 65-81.

Krakowiak, Fernando. 2013. 'Es un hito en la integración', Página 12, 17 May. Available at: http:// www.pagina12.com.ar/diario/economia/2-220188-2013-05-17.html [Accessed on 5 January 2015].

Le Prioux, Bruna, and Edmilson Moutinho dos Santos. 2011. 'A energia nuclear como instrumento de inserção internacional do Brasil: uma análise introdutória a partir da teoria poli-heurística de tomada de decisão'. Carta Internacional 6(1): 39-52.

Lima, Maria Regina Soares de. 2013a. The Political Economy of Brazilian Foreign Policy: nuclear energy, trade and Itaipu. Brasilia: FUNAG.

2013b. 'Relações Internacionais e políticas públicas: a contribuição da análise de política

externa. In Eduardo Marques and Cesar De Faria. A Política Pública como campo multidisciplinar, San Pablo: UNESP.

Madison, James. 2000. 'Agenda-building and big science'. Policy Sciences 33(1): 31-53.

Malacalza, Bernabé. 2014. 'La política de cooperación al desarrollo como dimensión de la política exterior desde la Teoría de las Relaciones Internacionales'. Revista Mural Internacional 5(2). 
Mallea, Rodrigo. 2012. La cuestión nuclear en la relación argentino-brasileña (1968-1984). MA Dissertation, Programa de Pós-Graduação em Ciência Política, da Universidade do Estado do Rio de Janeiro.

Merke, Federico. 2012. 'Brasil, política exterior y programa nuclear'. In Khatchik Der Goughassian (ed), La defensa en el siglo XXI. Argentina y la seguridad regional. Buenos Aires: Capital Intelectual.

Milani, Carlos and Leticia Pinheiro. 2013. 'Política externa brasileira: os desafios de sua caracterização como política pública’. Contexto Internacional 35(1): 11-41.

Patti, Carlo. 2013. 'O programa nuclear brasileiro entre passado e futuro'. Boletim Meridiano 47, 14(140): 49-55.

PER-ARCAL. 2014. Perfil estratégico regional para América Latina y el Caribe 2016-2021. Available at: http://www.arcal-lac.org/index.php/es/documentos. [Accessed on 2 January 2015].

Porta, Fernando, Diana Suárez and Jesica De Ángelis. 2010. 'Sistemas nacionales de Innovación en el MERCOSUR. Convergencias y Asimetrías'. In Gerardo Caetano (ed), 20 años del MERCOSUR. Montevideo: CEFIR.

Ribeiro, Maria Clotilde Meirelles, and Amilcar Baiardi. 2014. 'International Co-operation in Science and Technology: Reflecting about Concepts and Contemporary Issues'. Contexto Internacional 36(2): 585-521.

Sabato, Jorge A and Jairam Ramesh. 1980. 'Atoms for the third World'. Bulletin of the Atomic Scientists 36 (3): 36-43.

Scartascini C, Pablo Spiller et al. 2008. Policymaking in Latin America: How Politics Shapes Policies. Washington: Inter-American Development Bank.

Sebastian, Jesús. 2007. 'Conocimiento, cooperación y desarrollo', Revista Iberoamericana de Ciencia, Tecnología y Sociedad 3(8): 195-208.

Skolnikoff, Eugene B. 1994. The elusive transformation: science, technology, and the evolution of international politics. New Jersey: Princeton University Press.

Solingen, Etel. 1996. Industrial policy, technology, and international bargaining: Designing nuclear industries in Argentina and Brazil. Redwood City: Stanford University Press.

Thomas, Hernán, Mariano Versino and Alberto Lalouf. 2008. 'La producción de tecnología nuclear en Argentina: el caso de la empresa INVAP’. Desarrollo Económico: 543-575.

Troyjo, Marcos. 2003. Tecnologia \& diplomacia: desafios da cooperação internacional no campo científico-tecnológico. São Paulo: Aduaneiras.

Wagner, Caroline. 2006. 'International collaboration in science and technology: Promises and pitfalls'. In Box De la Rive and Rutger Engelhard. 2006. Science and Technology Policy for Development. New York / London: Anthem Press.

2002. 'Science and foreign policy: The elusive partnership'. Science and Public Policy 29(6): 409-417.

et al. 2011. Science and Technology Collaboration: Building Capacity in Developing Countries? Santa Monica: RAND.

Wagner, Caroline, Allison Yezril and Scott Hassell. 2001. International Co-operation in Research and Development: An Inventory of U.S. Government Spending and a Framework for Measuring Benefits. Santa Monica: RAND. 


\section{Acknowledgements}

The author acknowledges the support of the program REDES (Argentine Ministry of Education), an academic network formed by UNQ, National University of San Martin (UNSAM) and IESP-UERJ, and is grateful for comments and observations from Monica Hirst.

\section{About the author}

Prof Bernabé Malacalza holds a PhD in social sciences from the Latin American Faculty of Social Sciences (FLACSO), a master's degree in international economic relations from the University of Barcelona, Spain, and a master's degree in international relations and negotiations from the University of San Andrés and FLACSO. He is currently an assistant researcher at the National Scientific and Technical Research Council (CONICET) in Argentina, based at the National University of Quilmes (UNQ). He is also professor at the $\mathrm{PhD}$ in economic development at UNQ; professor of international co-operation at the National University of San Martin (UNSAM). Email b.malacalza@conicet.gov.ar

Received on 14 January 2015, and approved for publication on 30 September 2015. 